\title{
Water reallocation policies: public perceptions
}

\author{
H. Bjornlund ${ }^{1,2,3}$, A. Zuo ${ }^{1}$, C. Parrack ${ }^{3}$, S. Wheeler ${ }^{1}$ \& R. de Loë ${ }^{3}$ \\ ${ }^{I}$ Centre for Regulation and Market Analysis, \\ University of South Australia, Australia \\ ${ }^{2}$ University of Lethbridge, Canada \\ ${ }^{3}$ University of Waterloo, Canada
}

\begin{abstract}
The need for mechanisms to facilitate a reallocation of water to meet demands from new users and to improve the environmental conditions of many rivers in semiarid regions of the world is increasing. Given past allocation policies, which have vested control of often more than $80 \%$ of water resources with irrigators, this will require a reallocation of water out of irrigation. Such reallocation can take place in many ways but is likely to cause pain for irrigators and their communities. This paper investigates the acceptance of water reallocation policies in the context of Alberta, Canada. We explore the influences of demographic and attitudes on the acceptance of water reallocation policies and investigate whether such acceptance differs between urban and rural residents. We find that urban dwellers are more likely to favour government intervention while rural dwellers are more likely to support policies that aim to protect irrigators' water rights. We also find that people, both in urban and rural areas, can be divided into three groups depending on their values and attitudes towards water and the environment: 1) pro-environment; 2) pro-economic and 3) undecided. The urban resident is more likely to belong to the pro-environmental group while rural residents are more likely to belong to the undecided group. Keywords: water reallocation, environmental needs, rural urban differences.
\end{abstract}

\section{Introduction}

There is growing pressure on many water resources throughout the world, especially in semiarid regions. Population and economic growth as well as urbanization have caused water extraction to increase to critical levels so that many of the worlds' major rivers no longer flow into the oceans during long 
periods and where water quality is declining to critical levels for human consumption, economic use and ecosystem health [1]. This has resulted in increasing demand from concerned citizens to leave more water in the rivers. In response, some governments have stopped issuing new rights to extract water and are exploring options for reducing extraction of water for consumptive use and facilitating a reallocation of water to meet new and changing demand and to maintain economic growth.

Irrigated agriculture in many semi-arid regions controls around $80 \%$ of the water. Consequently the irrigation sector will be the major source of water for reallocation. The major recipients of this water will be growing urban centres and industries as well as the environment. Reducing the irrigation sector's access to water will have negative socioeconomic impacts on current irrigators and their communities, and may potentially threaten food security. If irrigators' access to water is reduced, then their productivity, and thereby profitability, will go down and the value of their property will decline. Similarly, if a region experiences reduced farm production then the economic activity in that region will go down resulting in fewer jobs, a declining population and a loss of community services and businesses.

How severe this impact will be depends on the policies and instruments used to facilitate the reallocation. Governments have several options. One option is to introduce water markets to facilitate a reallocation between current and new users and between existing users. Reallocation between irrigators is an important element as it allows the water retained in irrigation to move to the most efficient and highest value producers and hence reduces the impact of total production in the area.

Water markets allow reallocation to take place as a voluntary process between willing sellers and buyers, where the buyers presumably compensate the sellers for their losses. Markets can also secure water for the environment, either by governments buying water back from irrigators or by privates or nongovernment organizations buying water and leaving it in the river or apply it to wetlands.

Governments can choose to use more draconian measures, the can: i) decide how much water the environment needs and not allow consumptive users access to the water until these needs are met; and ii) withdraw the right to use water from one user and grant it to another. In some jurisdictions these process could take place within current legislation, in other they will require legislative changes, while in some it might raise issues of compensation. However, such solutions are expensive in political terms. Government can try to minimize the political cost by supporting/compensating the affected irrigators and providing structural adjustment assistance to communities and farmers. This will involve the spending of tax payers' money. If the general public does not accept the solution, then this might also be associated with political cost. As a result policy changes in the area of water allocation have been slow and hesitant because policy makers tend to postpone tough decisions that have negative electoral consequences as long as possible.

While it is imperative to introduce reallocation policies that are acceptable to irrigators and their communities to ensure their collaboration and participation, it 
is also critical to secure the acceptance of the rest of the population. In most places the biggest electoral risk, and most of the tax revenue, comes from urban centres. This is where this paper makes it contribution, using the situation in Southern Alberta as a case study. We explores how citizens in smaller and larger towns more or less dependent on irrigation perceive policy options to reallocated water and whether such perceptions vary depending on proximity to irrigation, on demographic characteristics or the values and attitudes that people hold toward the environment.

The next section provides the Alberta context and explains why the South Saskatchewan River Basin (SSRB) provides a unique opportunity to explore these issues. The following section briefly outlines the policy options explored and the parameters used to determine their acceptability. We then discuss the findings and draw some policy implications.

\section{The Alberta context}

Canada is normally perceived to have plenty of water. However, water is unevenly distributed; it is abundant in Central Canada, in the North and along the West Coast, whereas the southern part of the Prairie Provinces is very dry and scarcity is developing in other parts such as the Okanagan Valley in British Colombia and some watersheds in Ontario. Nowhere is scarcity worse than in the SSRB in Southern Alberta, home to some $60 \%$ of all irrigation in Canada [2].

Concern over excessive extraction started to emerge in the late 1980s and the first step to address this was taken in 1991 when Alberta Environment capped water allocation for irrigation. Concerns increased with a severe drought in 2001 resulting in Alberta environment placing a moratorium on new surface water licenses in the southern tributaries of the Oldman River [3]. In 2003 the Alberta Government released its Water for Life strategy acknowledging that without significant policy changes future demand from extractive and environmental purposes would outstrip supply. The strategy relies heavily on improved water use efficiency and productivity and voluntary reallocation of the saved water as the means to meet new demand. The use of market based instruments, best management practices and public participation in water planning was seen as integral tools in this process.

The urgency of policy reform was emphasized when the background paper for the Draft South Saskatchewan River Basin Management Plan was released in 2005 [4]. This document noted that:

- 22 of 33 main rivers are suffering moderate environmental effect from water stress caused by current levels of water extraction, 5 more are suffering heavier environmental losses and 3 are environmentally degraded;

- Demand from non-irrigation users could increase by $35-67 \%$ by 2021 and by $52-136 \%$ by 2046 ;

- Irrigation districts could expand by $10 \%$ and $20 \%$ in the Oldman and Bow River Basins respectively; and 
- the population in the SSRB is expected to grow from about 1.3 million to more than 2 million by 2021 and more than 3 million by 2046 .

As a consequence the Alberta Government announced that it would no longer accept new applications for licenses within the SSRB. This increased the need for effective reallocation mechanisms to ensure that new demands can continue to be met. Water markets were introduced with the Water Act in 1999 and the Irrigation Districts Act in 2000. However, the uptake of water markets has been very slow. There were some activities in the markets for assignments of the short term right to use water during the 2001 [5]. The use of the market in water licenses, or the long term right to access water has been very limited [6]. A survey of the managers and board members of the 13 irrigation districts found a very low level of acceptance of markets and other economic instruments. The survey also found that the sector believes that water saved through efficiency improvements should be used to expand irrigation and not to meet new demand from other users [7]. Considering the emphasis that the Water for Life strategy places on voluntary reallocation of water these findings raise doubt about the effectiveness of the strategy.

Two recent developments in Alberta have further illustrated the opposition to water trading as a mechanism for water reallocation throughout the community. The first occurred in 2007 when a developer wanted to undertake a major development of a shopping centre, race track and Casino at Balzac north of Calgary. The City of Calgary refused to supply the water. The developer then tried to source the water from the Red Deer River where new licences were still being issued. This would require an inter basin transfer which, under the Water Act, is only possible with ministerial consent which was not forthcoming due to public opposition. Finally the developer made a deal with the Western Irrigation District (WID) to buy 2,500 ML for 15 million dollars which the WID would use to line a leaking canal and thereby save more than the 2,500 ML. However, under the Irrigation District Act the WID needs the acceptance of such a transfer by a plebiscite amongst its irrigators. This caused significant debate within the WID and was only approved by a very narrow margin (54\% versus $46 \%$ ). Irrigators were concerned about giving up their long term control of the water even though the replacement of the canal would secure them access to more water. Opposition was also raised from the environmental sector, and an electricity producer launched a legal challenge that was eventually rejected [8].

The second case was an attempt by the Eastern Irrigation District (EID) to amend two of its licenses to allow them to supply 940,000 ML to users other than irrigation. Acknowledging the opposition amongst irrigators to selling parts of their water licenses as expressed in the Balzac transfer and in the survey by Bjornlund et al. [7], many districts want to find ways of delivering water to other users while retaining the ownership of the water. The Irrigation District Act enables districts to enter into contracts to supply water. However, to do that the districts license must allow this. Such amendments were granted to the St Mary River Irrigation District in 2003 despite opposition from environmental interests claiming that it undermined the purposes and spirit of the Water Act, which places strong emphasis of the public interest in water resources [9]. Other 
districts have been granted similar amendments. However when the EID submitted its application it met strong opposition from the environmental sector. It argued that such amendments allowed the districts to provide water to any person or purpose at whatever price they can obtain which in effect is a way of circumventing the environmental assessments required for the formal transfer of water license. This campaign was successful and Alberta Environment stopped the amendment process until further investigation could be carried out [10].

While both of these cases are very much in the spirit of the Water for Life Strategy they have been opposed by all sectors of the community. This threatens the process of achieving the Water for Life objectives so essential for Alberta's long term wellbeing. The two cases also illustrate the need to understand what drives this opposition in the community and how the community perceives that these reallocation processes should take place - which is one of the purposes of this paper.

While the current water planning processes define Water Conservation Objectives for all watersheds in Alberta they will be secured by licenses issued on the date the plan is approved. Within all stressed water sheds and under the Prior Allocation system, which secures access to use water in order of priority, it is unlikely that there will be water available for water conservation objectives during periods of drought. The Alberta Government is aware that further changes to the allocation system are needed. Three major studies were undertaken in 2009 to assist this process [10-13].

\section{The policy options explored in this study}

The paper summarizes two studies conducted based on a survey in and around Lethbridge, the regional centre of the most intensively irrigated region in Canada and the surrounding small towns $[14,15]$. While Lethbridge is at the centre of irrigation, it is not totally dependent on irrigation. It has a population of more than 84,000 and has a significant education sectors including a university, Canada's largest agricultural research station, and a community college. The surrounding small Towns (Taber, Magrath, Raymond and Stirling) have populations in the region of 2,000 people and are totally dependent on irrigation for economic activity and job creation.

The questionnaire used for the survey included 40 value statements reflecting different ways people value water and ten policy statements related to how water reallocation should take place and how water for the environment should be secured. In addition the questionnaires included a number of demographic and socioeconomic variables including recreational use of water and proximity to the irrigation industry.

The first study applied cluster analysis to the urban and rural respondents separately using the responses to the value statements and grouped respondents with like values, it was then explored how such cluster groups perceived policies differently and how the urban and rural clusters differ in perception [14]. The second study applied factor analysis to the value statements and used the factor scores as independent variables in regression analyses, together with personal 
and socioeconomic variables, as well as an indication whether the respondent came from an urban or rural area [15]. The ten policy options were grouped into three policy directions: government intervention; environmental protection; and the protection of irrigators' rights (Table 1). An index was computed for each respondent measuring the level of agreement with each policy direction. These measures were the dependent variables.

Table 1: $\quad$ Three water management orientations (Source [15]).

1. The government, rather than market forces, should decide who
gets to use Alberta's water.
2. If water is to be traded among irrigation districts and/or
municipalities, the government should set the price.
3. If an irrigation district or municipality is not using all of the water
it has been allocated, then the government should be able to take that
water for environmental purposes without compensation.
1. Private individuals and groups should be able to hold water
licenses for environmental protection.
2. Public funds should be used to improve irrigation systems only if
the water that is saved is left in rivers.
3. The government should buy water from current water license
holders, such as irrigation districts, so that more water can be left in
the river for the environment.
4. Minimum flows of water should be set for all rivers, and only the
water above those minimum flows should be available for economic
purposes such as irrigation.
1. All water licenses, no matter when they were issued or for what
purpose, must be honored.
2. Public funds should be used to help larger water users (irrigators,
industries and municipalities) to become more water efficient.
3. Water that is saved through improved water use efficiency should
be used to increase economic activity.
GOV-Government intervention; ENV-Environment Protection; IRR-Irrigators' right.

\section{Exploring policy differences}

In general the residents of Lethbridge are significantly more likely to agree with value statements that place importance on environmental water values and the preference for water conservation over water extraction, and government's responsibility for water protection. Reflecting this, they are also more likely to agree with policy options that recognize the environment's right to water and the government's role in water policy. On the other hand the residents of the surrounding small rural towns are significantly more likely to agree with value statements reflecting the direct economic use of water and the rights of irrigators. Reflecting this they are significantly more likely to support policy statement 
favouring the direct use of water and the rights of irrigators. These simple findings indicate significant differences between urban and rural people in the values they hold toward the environment and their policy preferences [15].

Factor analysis applied to the total sample revealed three value constructs. The first reflects the belief that the economic use of water is most important; it was therefore named economic. The second factor reflects the belief that water has most value when used for the environment and the community in general; it was therefore named environmental. The third factor reflects the belief that irrigators' property rights in water should be secure and that people who own water right have the right to use it to generate income; it was therefore named property.

Regression analyses [15] support the findings of the initial statistical analysis and suggest that urban residents are significantly more supportive of government intervention (consistent with [16-19]) while they are less supportive of irrigators' water rights. While they are also more supportive of environmental protection, this difference is not statistically significant (also found by $[19,20]$ [19]).

Importantly it was also found that the formation of policy preferences is far more complex than place of residence. Peoples' values and attitudes were found to have a significant influence on their policy preferences: i) the stronger a person aligns with the economic value construct the less they support government intervention and environmental protection but the more they support irrigators' water rights; ii) the stronger a person aligns with the environmental value construct the more they support the environment and irrigators' rights; iii ) the stronger a person align with the property rights value construct the less they support government intervention and the more they support irrigators' rights. This confirms a strong relationship between people's values towards water and their water policy preferences as also found by [21] and [22]. Other significant influencing factors identified were:

- males are more oriented towards government intervention and less oriented towards environmental protection or irrigators' property rights;

- members of watershed stewardship group are less oriented towards government intervention or environment protection and more supportive of irrigators' rights. This likely reflects that most water stewardship groups consist of land owners;

- personal characteristics:

$\circ$ older people, those with higher incomes, and those employed in the art, culture, recreation or sport areas are more oriented towards the need for government intervention;

$\circ$ people who do not regularly use water for recreational activities are less oriented towards environmental protection; and

$\circ$ people who are employed in the primary industries are more oriented towards irrigators' property rights. 
Confirming that other factors than residence play an important role in forming policy preferences the analysis identified relatively few factors which influenced urban and rural residents differently [15]. Those identified were:

- urban residents are more supportive of the government intervention policy if they do not regularly use water for recreation;

- the influence of working in the art, culture, recreation or sport sector is only significant for urban respondents;

- rural residents are significantly less likely to support the environmental policy orientation if they were members of stewardship groups, were blue collar workers or did not regularly participate in water recreation activities;

- education level only influences policy preferences amongst urban respondents;

- $\quad$ rural residents are less likely to support the role of the government the more they aligned themselves with the economic value construct.

These findings suggests that residential location has little influence on the magnitude of association between people's attitudes towards water and personal characteristics and their subsequent policy preference for water reallocation. This confirms that while place of residence has a significant impact other factors play a significant role as well.

The cluster analyses identified three clusters of respondents within both the urban and rural population (Table 2) [14]. The first cluster represents a proenvironment group, the second a pro-economic use of water group, while the third seems to be made up of people which are largely undecided or who are struggling to balance the environmental and economic needs.

While the same three main clusters emerged, the size of membership varied significantly (Table 2). There are also significant differences in how strongly each group within the rural and urban sample align themselves with the value statements. By far the largest cluster group is the urban pro-environment group which is not unexpected. However, the facts that a larger proportion of the urban population, compared to the rural population, belongs to the pro-economic group and that more rural people belong to the pro-environmental group than to the pro-economic group are surprising and counter to the literature [23-25]. The second largest group was the rural undecided. This group seems to represent a group of people who are aware of the environmental need for water but are concerned about the impact of policies trying to meet that need. They seem to be willing to make personal sacrifices in order to meet those needs but are unwilling to sacrifice what they consider to be the long term viability of the irrigation sector and their community.

Members of the pro-economic clusters are most in support of policies that involve retaining water within the irrigation sector and opposed policies to move water out of the sector for the environment. Similarly, members of the proenvironment clusters are opposed to policies giving priority to water for economic expansion, while supporting policies promoting environmental protection, prioritizing the need of the environment over economic needs and the reallocation of water from large licence holders to the environment. 
Table 2: $\quad$ Rural and Urban clusters (Source: Parrack [14]).

\begin{tabular}{|c|c|c|c|}
\hline Cluster Pair & Rural & Urban & Total \\
\hline \multicolumn{4}{|l|}{ Pro-Environment (RVC1 \& UVC1) } \\
\hline \% within Sample (rural or urban) & 38.3 & 62.3 & 52.0 \\
\hline$\%$ of Total Respondents & 16.5 & 35.5 & 52.0 \\
\hline \multicolumn{4}{|l|}{ Pro-Economic (RVC3 \& UVC2) } \\
\hline \% within Sample (rural or urban) & 13.3 & 21.1 & 17.6 \\
\hline$\%$ of Total Respondents & 5.6 & 12.0 & 17.6 \\
\hline \multicolumn{4}{|l|}{ Undecided (RVC2 \& UVC3) } \\
\hline$\%$ within Sample (rural or urban) & 48.6 & 16.6 & 30.4 \\
\hline$\%$ of Total Respondents & 20.9 & 9.5 & 30.4 \\
\hline
\end{tabular}

The urban undecided cluster was more supportive of pro-environment policies and the rural undecided more supportive of policies to protect the interests of the irrigation sector. However, members of the rural undecided cluster were more supportive of the idea that private individuals and groups should be permitted to hold water licences for environmental purposes. This further supports the argument that although members of the rural undecided cluster are supportive of the irrigation sector, they approve of policies that protect the environment through actions that do not negatively impact the irrigation sector.

\section{Conclusions}

This paper has explored the factors influencing urban and rural residents' policy preferences regarding how to facilitate water reallocation and the provision of water for the environment. While the findings partly support the existing literature in suggesting that place of residence (rural or urban) influence policy choice they also indicates that the process of policy choice is far more complex than that. There are clear significant links between people's values and attitudes towards water and the environment as well as personal characteristics and their policy preferences and that these influences are relatively consistent between rural and urban residents.

The finding that the urban residents are more polarized by either belonging to the pro-environment or pro-economic clusters suggests that people living in urban areas are not nearly as likely to be directly impacted by changes to water policies as do the rural residents. Hence it is easier for them to take either the one or the other more extreme views. This conclusion is supported by the fact that almost half the rural population is undecided and while willing to make personal sacrifices to meet the needs of the environment, oppose policies which the perceive will threaten the viability of the irrigation sector and their communities. 


\section{References}

[1] Dyson, M., Bergkamp, G., and Scanlon, J., Flow: The Essentials of Environmental Flows. Gland, Switzerland, The World Conservation Union, 2003

[2] Statistics Canada, Agricultural Water Use Survey (survey no. 5145). Accessed on 31/07/09 at www.statcan.gc.ca/pub/16-001-m/2009008/t008eng.htm, 2007

[3] Alberta Environment, Summary, SSRB Background studies. Edmonton, AE, 2003

[4] Alberta Environment, Background Information for public consultation on the South Saskatchewan River Basin's Draft Water Management. AE, 2005

[5] Nicol, L. and K. Klein, Water market characteristics: Results from a survey of Southern Alberta irrigators. Canadian Water Resources Journal, 31(2): 91-104, 2006

[6] Nicol, L., K. Klein, and H. Bjornlund, Permanent Transfers of water rights: A study of the southern Alberta market. Prairie Forum 33(2), 341-56, 2008

[7] Bjornlund, H., L. Nicol and K. Klein, Challenges in Implementing Economic Instruments to Manage Irrigation Water on Farms in Southern Alberta. Journal of Agricultural Water Management 92, 131-141, 2007.

[8] Bjornlund, H., L. Nicol, and K. Klein, The Adoption of Improved Irrigation Technology and Management Practices - A Study of Two Irrigation Districts in Alberta, Canada. Journal of Agricultural Water Management 96, 121-131, 2009.

[9] Banks, N. and A. Kwasniak, St. Mary's Irrigation District licence amendment decision: Irrigation districts as a law unto themselves. Journal of Environmental Law and Practice, 16: 1-18, 2005.

[10] Bjornlund, H., The Competition for Water: Striking a Balance among Social, Environmental and Economic Needs. Commentary No 302: Governance and Public Institution, C.D. Howe Institute, Toronto, 2010.

[11] Minister's Advisory Group, Recommendations for improving Alberta's Water management and Allocation. Ministers Advisory group, Edmonton, 2009

[12] Alberta Water Council, Recommendations for improving Alberta's water transfer system. AWC, 2009.

[13] Alberta Water Research Institute (2009): Towards Sustainability Phase 1: Ideas and Opportunities for improving Allocation and Management in Alberta. Alberta Water Research Institute, Edmonton.

[14] Parrak, C., The Influence of Stakeholder Values on the Acceptance of Water Reallocation Policy in Southern Alberta, Master's Thesis, University of Waterloo, 2010

[15] Bjornlund, H., A. Zuo, S. Wheeler' and R. de Loë, Water Reallocation Policies - the importance of rural and urban differences in Alberta, Canada. Paper submitted to Environment and Planning $C$ 
[16] Lowe, G.D. and C.W. Peek, Location and lifestyle: the comparative Explanatory Ability of Urbanism and Rurality. Rural Sociology 39(3); 392420, 1974.

[17] Avalos, M. and De Young, T., Preferences for water policy in the Ogallala region of New Mexico. Policy Studies Journal 23(4): 668-685, 1995.

[18] Demers, Chris, Long, Alan, Grob, Todd, McElvey, Chuck (Eds.). The Florida Forest Steward, vol. 7(2). 2000.

[19] Pumphrey, RG, Edwards, JA \& Becker, KG, Urban and rural attitudes toward municipal water controls: A study of a semi-arid region with limited water supplies, Ecologycal Economics, vol. 65, pp. 1 - 12, 2008.

[20] Jones, R. E. and Dunlap R. E., The social bases of environmental concern: Have they changed over time? Rural Sociology 57 (1): 28-47, 1992.

[21] Stern, PC \& Dietz, T, 'The value basis of environmental concern', Journal of Social Issues, vol. 50, no. 65-84, 1994.

[22] Stern, PC, 'Toward a coherent theory of environmentally significant behaviour', Journal of Social Issues, vol. 56, no. 3, pp. 407-424, 2000.

[23] Tremblay, K.R. and R.E. Dunlap Rural-urban residence and concern with environmental quality: A replication and extension. Paper presented at the Annual Meeting of the Rural Sociology Society, Madison, Wisconsin, 1977.

[24] Salka, W.M., Urban-rural conflict over environmental policy in the western United States. American Review of Public Administration, 31(1): 33-48, 2001.

[25] Jones, R.E., M.J. Fly, J. Talley and H.K., Green migration into rural America: The new frontier of environmentalism? Society and Natural Resource, 16: 221-238, 2003. 